第8回講習 日程 表

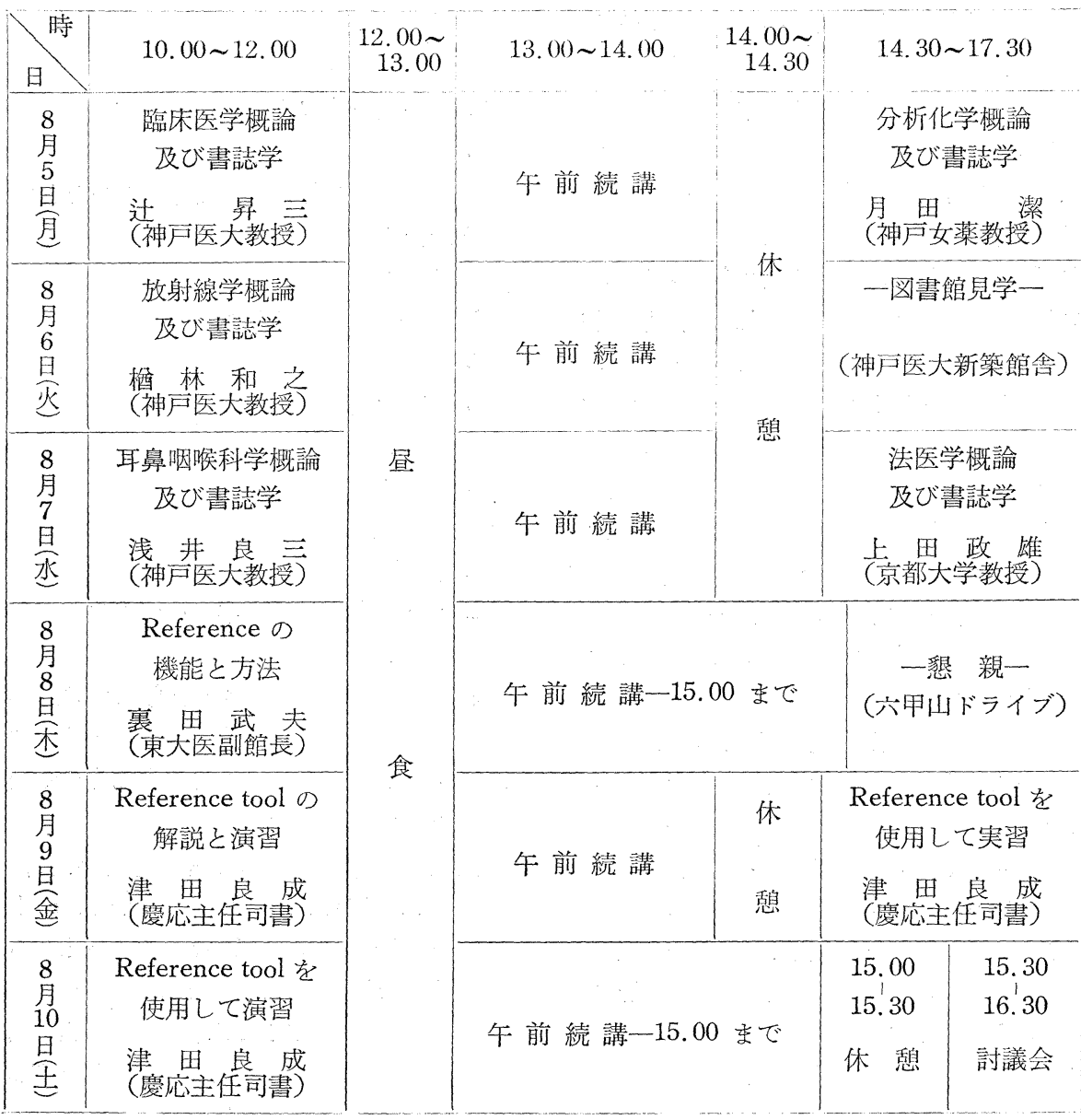

顕微鏡技術ハンドブック第 3 版

\title{
HANDBOOK of BASIC
} MICROTECHNIQUE 3rd Ed.

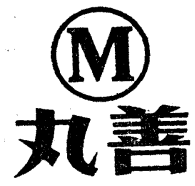

By Peter Gray (McGraw, N. Y.)

1964. 3 月刊行予定 予約受付中 概価 $¥ 2,800$ 